"Characteristics of Long Pneumatic Lines". Some useful data from aerodynamics is given in a thirty-page appendix. Restrictions are categorized as turbulent, laminar, and mixed flow types for the purpose of analysis and there is an interesting study of the effect of the eccentricity of the plug in an adjustable restriction. Pneumatic chambers are dealt with as flow and blank chambers in combination with restrictions and in a variety of banking arrangements. This section is rich in design data and gives several examples of design calculations. As for the chambers, the dynamic equations for long pipe-lines are derived and these equations are solved by methods analogous to those used for electrical transmission lines.

The book is written for the designer. While adequate theory is given when required, the plan is rather to state and explain formulae and give reforences to published work. It is a comprehensive review of knowledge in a limited field and presents this knowledge in a way which makes it readily available for design use. The bibliography has exactly a hundred references (ten to work by Zalmanzon), mostly to publications dated from 1950 and the most recent dated 1960 , which is as new as can be expected since the original volume was published in 1961 . Many of the references are to Russian papers and the titles of these are helpfully translated. There is no index other than a subject index of some sixty items, but this is not a serious lack since the contents are given in detail. W. McHutchison

\section{PLANT-GALLS OF EUROPE}

Bestimmungstabellen der Gallen (Zoo- und Phytocecidien) an Pflanzen Mittel- und Nordeuropas

Band 1. By Dr. phil. habil. Herbert Buhr. Pp. xvi +761 . (Jena: VEB Gustav Fischer Verlag, 1964.) 139s. 9d.

TF one were to describe this exhaustive treatise on the plant galls of Central and Northern Europe as a typical example of Teutonic thoroughness, it would be but to pay tribute to the undeniable German genius for this type of encyclopaedic production.

Bestimmungstabellen der Gallen (Zoo- und Phytocecidien) an Pflanzen Mittel- und Nordeuropas is arranged in the way which has been customary in previous systematic cecido. logical works, that is, strictly alphabetically by host genera; the first volume covers the genera Abies to Myrrhis. Cryptogamous hosts (algae, fungi, lichens) are also included. The information, though presented in key form, is rendered considerably more accessible and usable than is often the case with an amalgamated key-plus. description presentation by the judicious use of large and small type and other distinctive type-faces, combined with paragraphing and generous spacing. In his preface, the author expresses his appreciation of the co-operation which he experienced from his publishers and printers; and indeed author, publisher and printer alike deserve commendation for the evident care and thought that has been given to lay-out and production. The subsidiary small-type paragraphs under each gall-description include notes on distribution, bionomics, etc., together with copious references to literature.

The keys are preceded by a 64-page introductory section ("Allgemeiner 'Teil"), in which general aspects and problems of cecidology are discussed. Several pages are devotod to gall aetiology. "Galls arise in the course of mutual action and counteraction between the partners [host and parasite], in a constant opposition between normal and abnormal growth, as a compromise solution. All formative impulses originating from the parasites can only set in motion in the plants processes which fit into the framework of their hereditarily conferred morphogenetic capabilities." There is as yet, however, no agreement between authorities concerning the relative parts played in gall-formation by growth-promoting substances produced by the host-plant itself and by specific substances secreted by the parasite. Attention is directed to peculiar features in the biology of certain galls and their producers, such as the remarkable phenomenon of 'chlorophyll-conservation' in certain poplar-feeding Stigmella species (Lepidoptera) where the activity of the leaf-mining larva causes a retardation of the normal process of senescence in the surrounding tissues, which thus remain green until the larva has completed its development. In another section the author discusses the question, What is a gall ? He also details methods for the study and preservation of galls and their causative organisms.

The work is illustrated (at the end of Volume 2) by twenty-five plates, containing 443 figures, many of which are taken or re-drawn from Dunzinger's illustrations to the well-known work of Ross and Hedicke (1927), or from the more delicate drawings by Han Alta illustrating Docters van Leeuwen's much more recent (1957) handbook to the plant-galls of The Netherlands.

Prof. Martin Hering, the authority on leaf-miners, in his foreword directs attention to the fact that Dr. Buhr has not only dealt with galls of animal origin, but, unlike all his predecessors in the field, has also included those caused by fungi and other plant-parasites. This gives a unique value to the work. Prof. Hering also tells us that the author has devoted special care to providing the taxonomically and nomenclaturally correct names for the organisms mentioned.

On all counts, one must agree whole-heartedly with the claim of the publishers that this remarkable singlehanded production, the crown of a life-work of botanical, pharmacognostic, zoological and phytopathological study, represents a "unique scientific achievement".

H. K. AIRY SHAw

\section{SUGAR CANE RESEARCH}

Genetics and Breeding of Sugar Cane

By G. C. Stevenson. (Tropical Science Series.) Pp. $x i+284+51$ plates. (London: Longmans, Green and Co., Ltd., 1965.) 70s. net.

$T$ is a truism that if a crop is important, the interests which it serves, whether industrial or agricultural, usually spend a great deal of money on research. Such research is often carried out in special research institutes concerned only with one crop; this is the case with sugar cane, sugar beet, rubber, tea, coconuts, etc. This is as it should be, for if a crop has to compete with other crops for funds in an experimental station, it tends to suffer from lack of men, money, and equipment.

Genetics and Breeding of Sugar Cane is the third in the Tropical Science Series, the volumes of which serve to present detailed information about tropical crop plants. Such information is widely scattered in a large number of publications often hard to obtain.

The book has eight chapters, dealing respectively with taxonomy; the history of sugar cane improvement; flowering and its control; breeding methods; variation and inheritance; cytology; and breeding systems. There is a final chapter on "The Philosophy of Sugar Cane Breeding" which should be compulsory reading for all students of applied genetios.

The breeding methodology of any plant is dominated by a number of special features. In sugar eane these are: the onormous number of seedlings which can be raised, making it possible to screen adequately for resistance to pathogens, and to establish rigid standards for selection; the existence of several species with wide geographical extension and consequently a wide range of adaptability; and the extensive production of unreduced gametes, making possible the important phenomenon of the addition of genomes (nobilization). 